\title{
PERSONALITY TRAITS AND BUYING BEHAVIOR \\ FROM THE VIEWPOINT OF SELECTED SOCIO-DEMOGRAPHIC CHARACTERISTICS - PRELIMINARY FINDINGS
}

\author{
Tatiana Lorincová ${ }^{1}$ (i) \\ Ivana Ondrijová ${ }^{2}$ \\ Jana Koval'ová ${ }^{3}$
}

DOI: https://doi.org/10.31410/ITEMA.S.P.2019.99

\begin{abstract}
The aim of the study is to compare personality traits (extraversion, agreeableness, openness to experience, conscientiousness and neuroticism) and buying behavior among respondents from the $Y$ and $Z$ generations in the context of gender. The research sample consisted of 105 respondents aged between 18 and 65 years (average age: 32.34, standard deviation: 11.81). The sample included 57 women, 48 men, 32 respondents from generation $Y$ and 41 respondents from generation $Z$. A shortened version of the Big Five (Janovská 2011) questionnaire was used to explore the personality traits, which consists of 40 adjectives, where respondents answered on the scale from 1 - quite inaccurately to 8 - quite accurately. The Customers' buying behavior (CBB) authors' questionnaire consists of 7 items, where respondents rated by the Likert scale from 1 -doesn't matter at all to 5 -depends very much. The research results were processed in statistical program IBM SPSS 20.00 Statistics and assessed by T-test for two independent samples. Research results showed statistically significant gender differences in the level of extraversion, agreeableness and conscientiousness in favor of women. On the other hand, research results showed statistically significant difference in the level of extraversion between respondents from generation $Y$ and respondents from generation $Z$ in favor of respondents from generation $Z$. The limitation of research study is an occasional choice of research sample.
\end{abstract}

Keywords: Buying Behavior, Customer, Gender, Generation, Personality Traits

\section{THEORETICAL BACKGROUND}

Dersonality traits deal with temporally and situationally invariant personal characteristics that distinguish different individuals and lead to consistencies in behavior across situations and over time (McAdams, 2001). Personality traits can be measured by the popular Big Five model. It is defined as a hierarchical model with five broad factors, which represent personality at the broadest level of abstraction. "Each bipolar factor (e.g., extraversion vs. introversion) summarizes several more specific facets (e.g., sociability), which, in turn, subsume a large number of even more specific traits (e.g., talkative, outgoing). The Big Five framework suggests that most individual differences in human personality can be classified into five broad, empirically derived domains" (Gosling, Rentfrow \& Swann, 2003, p. 506).It focuses on a core set of behavioral traits: extraversion, neuroticism, agreeableness, conscientiousness and openness to experience and its proponents argue that people can be understood by knowing how much they display each of these five traits in their lives (Sheldon, Ryan, Rawsthorne \& Ilardi, 1997).

As McCrae and John (1992) explain, the model integrates a wide array of personality constructs, thus can be used in many areas of research. Also, it is comprehensive and gives basis

\footnotetext{
Prešovská univerzita v Prešove, Fakulta manažmentu, Konštantínova 16, 08001 Prešov, Slovakia

2 Prešovská univerzita v Prešove, Fakulta manažmentu, Konštantínova 16, 08001 Prešov, Slovakia

3 Prešovská univerzita v Prešove, Fakulta manažmentu, Konštantínova 16, 08001 Prešov, Slovakia,
} 
for exploration between personality traits and other indicators. Third benefit they point out is efficiency of the Big Five model, because of only five scores. Baumgartner (2002) states that "consumers' standing on the purchase-related traits could also be related to more basic dimensions of personality such as the Big Five factors in an effort to find out to what extent different purchase behaviors have their roots in more basic tendencies of the individual" (p. 289).According to the literature (Nga \& Ken Yien, 2013; Giovannini \& Thomas, 2015; Lin, 2011) we aimed our research to relationships between personality traits (measured with The Big Five model), generations (Horváthová \& Čopíková, 2015) and gender.

Generation is defined as people within a delineated population, who experience the same significant events within a given period of time (Robinson 2018). The differences in trade behavior among individual generations are dealt with in generational marketing that uses the generation segmentation in marketing communication (Kumar, 2014; Bačík et al., 2018).

Through the segmentation of customers, it is possible to acquire information enabling to create new products and services, to understand the different requirements and preferences or to know what customers appreciate (Mainland 2012). An overview of generations in Slovak conditions is shown in Picture 1.

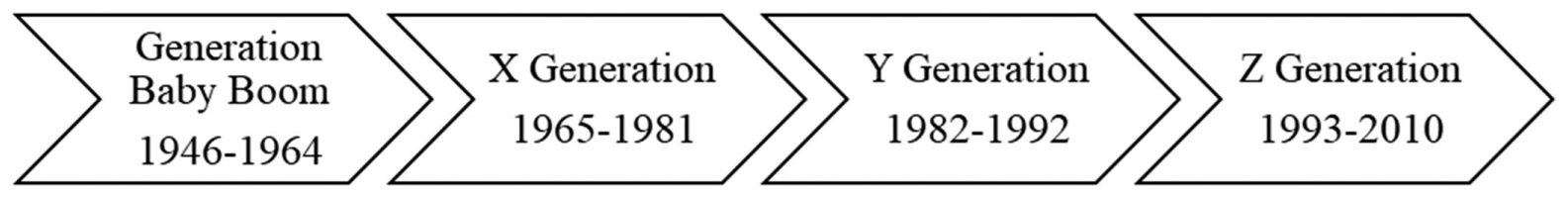

Picture 1. The boundaries of the years for individual generations

Source: Horváthová \& Čopíková, 2015.

The Baby Boom generation refers to people born during economic prosperity after World War II in the USA (1946 - 1964). They grew up in a stable period believing that they have political and social responsibility and can influence the world they live in (Mainland 2012; Hansen \& Leuty 2012). Baby Boomers are confident, independent, and self-reliant. Their negative feature is avoiding changes and insufficient adaptability (Kane 2019). They are attracted to the foreign or exotic and reject high fashion, imitations, and fakes (Littrell, Jin Ma \& Halepete, 2005). Baby Boomers "want to know how a product was made, who made it, and what will happen to it when they are done with it" (Ray, 1997, p. 32). For the purposes of research study, the determination of years for generation $\mathrm{X}$ is the range of customers born between years $1965-1981$. As Wroblewski (2018) claims, this generation highly values freedom and independence. They are competitive, self-assertive and hardworking, on the other hand individualistic and less loyal. They prefer balance between a working and private life. Customers in the $\mathrm{X}$ generation, can be gained by marketing staff through media means that are fragmented and reasonless. They better respond on product design, which has more diversified choices (Lin, 2011). The customers of generation Y (1982-1992) are able to actively search, classify, filter and analyze needed information. This generation is more resistant and skeptical to traditional marketing tools and tactics as the previous generations (Hershatter \& Eprstein 2010; Broadbridge et al. 2007). Generation Y consumers are viewed as being high public self-conscious individuals and are more likely to be brand conscious when making purchase decisions (Giovannini \& Thomas, 2015). For this generation, the uniqueness of the product can be enhanced to create an atmosphere that is new and unconventional to allow them to have the sense of superiority of being different (Lin, 2011). For the generation Z (1993-2010), according to IBM (2017) technologies are still a natural part 
of their life and require a higher standard as the previous generations. They are accustomed to high-tech and multiple information sources, with messages from all sides. They have never lived without the Internet. Generation $\mathrm{Z}$ values authenticity and realness. From the marketing view they are discerning consumers who think a lot about what they are going to wear and the purchases they make themselves (Williams \& Page, 2011).

The last facet of research study is comparison of customer buying behavior in the context of gender. Birknerová, Frankovský, Zbihlejová \& Parová (2017) explain gender in three levels: socio-structural level, interpersonal level and individual level. There are a number of studies that confirm different buying behaviors from a gender perspective. As Benko \& Pelster (2013) report, women in buying behavior tend to collect important information during the actual purchasing process. They enter the shop with a certain idea, but they are also open to the other possibilities that occur during the meeting itself. Men focus their attention on a particular role and do not change their plans and activities during the purchasing process. They trust more in their judgment and decide faster than women. Jones et al. (1998) examined the role of gender in forming a relationship between seller and buyer. They found that the perception of this relationship depended on the seller's and the buyer's gender, the relationship being perceived as stronger when the seller and the buyer are of the same gender. In the study Homburg \& Stock (2005) is shown that the relationship between the seller and the buyer is positively moderated by sellers' empathy, expertise and reliability. The research by Mitchell and Walsh (2006) shows that women are more perfectionist than men. Men are less sensitive to news and fashion and women are more likely to get confused.

\section{RESEARCH METHODOLOGY}

The main goal of the research is to compare personality traits and customer buying behavior in the context of gender and generation of respondents. Statistically significant differences are assuming in the level of personality traits and customer buying behavior in the context of generation.

\section{RESEARCH SAMPLE}

Research sample consisted of 105 respondents aged from 18 to 65 years (average age was 32.34 with standard deviation 11.807). The proportionality of gender was uneven- the sample contained 48 men and 57 women. The research sample consisted of 8 respondents from generation BB (year of birth 1946-1964), 24 respondents from generation X (year of birth 1965-1981), 32 respondents from generation Y (year of birth 1982-1992) and 41 respondents from generation Z (year of birth 1993-2010).The participants of the research were selected by using occasional selection.

\section{RESEARCH METHODS}

For research purpose were used two self-reported questionnaires. A shortened version of the Big Five questionnaire (Janovská, 2011) was used to explore the personality traits, which consists of 40 adjectives, where respondents answered on the scale from 1 - quite inaccurately to 8 - quite (accurately). Factors of Big five methodology (extraversion, neuroticism, agreeableness, conscientiousness and openness to experience) consist of 8 items. Shortened version of the Big Five questionnaire measures five personality traits (extraversion, neuroticism, agreeableness, conscientiousness and openness to experience). Cronbach's alpha was 0.79 . 
The Customers' buying behavior (CBB) authors' questionnaire consists of 7 items, where respondents rated by the Likert scale from 1 - doesn't matter at all to 5 - depends very much. Cronbach's alpha was 0.84 .

Example of items CBB questionnaire:

- To what extent do you care about the price of the products?

- To what extent do you care about the color design of the store?

\section{RESEARCH RESULTS}

The comparison of differences in the level of personality traits (extraversion, agreeableness, conscientiousness, openness to experience and neuroticism) and customers' buying behavior in the context of gender and generation of participants were assessed by using statistical method t-test for two independent samples and processed in statistical program IBM SPSS 20.00 Statistics. Table 1 shows statistically significant differences in the level personality traits and customers' buying behavior in the context of gender.

Table 1. Comparison of statistically significant gender differences in the level of personality traits and customers' buying behavior of participants

\begin{tabular}{|c|c|c|c|c|c|c|c|}
\hline & Gender & $\mathbf{n}$ & Mean & $\begin{array}{l}\text { Standard } \\
\text { Deviation }\end{array}$ & $\mathbf{t}$ & $\begin{array}{l}\text { Degree of } \\
\text { Freedom }\end{array}$ & $\mathbf{p}$ \\
\hline \multirow{2}{*}{ Extraversion } & Women & 57 & 6.188 & 0.832 & \multirow{2}{*}{2.442} & \multirow{2}{*}{103} & \multirow{2}{*}{0.016} \\
\hline & Men & 48 & 5.804 & 0.765 & & & \\
\hline \multirow{2}{*}{ Agreeableness } & Women & 57 & 6.493 & 0.838 & \multirow{2}{*}{3.243} & \multirow{2}{*}{103} & \multirow{2}{*}{0.002} \\
\hline & Men & 48 & 5.901 & 1.009 & & & \\
\hline \multirow{2}{*}{ Conscientiousness } & Women & 57 & 6.131 & 0.941 & \multirow{2}{*}{3.065} & \multirow{2}{*}{103} & \multirow{2}{*}{0.003} \\
\hline & Men & 48 & 5.562 & 0.956 & & & \\
\hline \multirow{2}{*}{ Openness to experience } & Women & 57 & 5.256 & 0.811 & \multirow{2}{*}{1.120} & \multirow{2}{*}{103} & \multirow{2}{*}{0.266} \\
\hline & Men & 48 & 5.057 & 1.012 & & & \\
\hline \multirow{2}{*}{ Neuroticism } & Women & 57 & 4.388 & 0.976 & \multirow{2}{*}{1.003} & \multirow{2}{*}{103} & \multirow{2}{*}{0.318} \\
\hline & Men & 48 & 4.187 & 1.074 & & & \\
\hline \multirow{2}{*}{ Buying behavior } & Women & 57 & 3.538 & 0.539 & \multirow{2}{*}{2.637} & \multirow{2}{*}{103} & \multirow{2}{*}{0.010} \\
\hline & Men & 48 & 3.244 & 0.605 & & & \\
\hline
\end{tabular}

Source: own processing

The comparison of means of gender differences is statistically significant in four cases. Statistically significant gender differences in the level of extraversion $(p=0.016)$ were detected. In the level of extraversion was the difference 0.384 in favor of women. Statistically gender differences were found in the level of agreeableness, conscientiousness and customers' buying behavior. In the level of agreeableness was the difference 0.592 in favor of women. In the level of conscientiousness was the difference 0.569 in favor of women. Finally, in the level of customers' buying behavior was the difference 0.294 in favor of women. Table 2 shows statistically significant differences in the level of personality traits and customers' buying behavior in the context of generation.

The comparison of means of differences in the context of generation was statistically significant in one case. Statistically significant differences were found in the level of extraversion $(\mathrm{p}=0.007)$. In the level of extraversion was the difference 0.488 in favor of participants from generation Z. In the level of agreeableness, conscientiousness, openness to experience, neuroticism and customers' buying behavior we did not find statistically significant differences. 
Table 2. Comparison of statistically significant differences in the level of personality traits and customers' buying behavior in the context of generation of participants

\begin{tabular}{|c|c|c|c|c|c|c|c|}
\hline & Generation & $\mathbf{n}$ & Mean & $\begin{array}{l}\text { Standard } \\
\text { Deviation }\end{array}$ & $\mathbf{t}$ & $\begin{array}{l}\text { Degree of } \\
\text { Freedom }\end{array}$ & $\mathbf{p}$ \\
\hline \multirow{2}{*}{ Extraversion } & Generation Y & 32 & 5.707 & 0.611 & \multirow{2}{*}{-2.755} & \multirow{2}{*}{69.812} & \multirow{2}{*}{$\mathbf{0 . 0 0 7}$} \\
\hline & Generation $\mathrm{Z}$ & 41 & 6.195 & 0.898 & & & \\
\hline \multirow{2}{*}{ Agreeableness } & Generation Y & 32 & 5.871 & 0.933 & \multirow{2}{*}{-1.700} & \multirow{2}{*}{71} & \multirow{2}{*}{0.093} \\
\hline & Generation Z & 41 & 6.253 & 0.967 & & & \\
\hline \multirow{2}{*}{ Conscientiousness } & Generation Y & 32 & 5.558 & 0.925 & \multirow{2}{*}{-0.610} & \multirow{2}{*}{71} & \multirow{2}{*}{0.544} \\
\hline & Generation Z & 41 & 5.695 & 0.966 & & & \\
\hline \multirow{2}{*}{ Openness to experience } & Generation Y & 32 & 4.949 & 1.051 & \multirow{2}{*}{-1.899} & \multirow{2}{*}{71} & \multirow{2}{*}{0.063} \\
\hline & Generation Z & 41 & 5.375 & 0.874 & & & \\
\hline \multirow{2}{*}{ Neuroticism } & Generation Y & 32 & 4.265 & 0.976 & \multirow{2}{*}{-0.358} & \multirow{2}{*}{71} & \multirow{2}{*}{0.722} \\
\hline & Generation Z & 41 & 4.357 & 1.151 & & & \\
\hline \multirow{2}{*}{ Buying behavior } & Generation Y & 32 & 3.281 & 0.525 & \multirow{2}{*}{-1.641} & \multirow{2}{*}{71} & \multirow{2}{*}{0.105} \\
\hline & Generation Z & 41 & 3.512 & 0.646 & & & \\
\hline
\end{tabular}

Source: own processing

\section{DISCUSSION AND CONCLUSION}

The aim of the study was to compare personality traits (extraversion, agreeableness, openness to experience, conscientiousness and neuroticism) and customers' buying behavior among respondents from the $\mathrm{Y}$ and $\mathrm{Z}$ generations in the context of gender. The research results were processed in statistical program IBM SPSS 20.00 Statistics and assessed by T- test for two independent samples.

The use of the Big five methodology in relation to customers' buying behavior has found application in many studies. The recent study of Ratnawat \& Borgave (2019) was focused on investigation of Big-Five personality to impulsive buying behavior. The data for the present study were collected from 178 respondents and random sampling in India was chosen as the technique. In this study agreeableness and neuroticism significantly correlated with impulsive buying behavior. Vice versa extraversion, openness and conscientiousness practically did not have correlations with impulsive buying behavior.

Results of the study showed statistically significant gender differences in the level of extraversion, agreeableness and conscientiousness in favor of women. Women scored higher than men in the level of extraversion, agreeableness, conscientiousness and customers' buying behavior. Similarly, McCrae \& Cost (1990) refer to gender differences concerning to the Big Five model such that women tend to show higher scores on agreeableness and neuroticism, are evident in different cultural contexts.

In the generational context, on the base of analyses were confirmed statistically significant difference only in the level of extraversion between customers from generation Y and Z. In this identified statistically significant difference, customers from the generation $\mathrm{Z}$ scored higher than customer from the Generation Y. The customers from younger Generation Z are more extroverted than the Generation Y.

These findings are consistent with earlier studies (Ratnawat \& Borgave 2019; Farwizah, Rahim \& Abd Rahim 2018; Ercis \& Unalan 2017; McCrae \& Costa 1990). All these findings point out to importance of knowledge different personality traits in the context of customers' buying behav- 
ior from the point of view of gender and generation of customers. This issue creates space for future research that has a general and interdisciplinary character. The limitation of research study is an occasional choice of research sample and low number of respondents. The research results are basis for future research with more socio - demographic and personality characteristics.

\section{ACKNOWLEDGMENT}

Scientific paper was elaborated within the framework of the project KEGA 0033PU-4/2017 Implementation of interpersonal skills in the context of the Psychology of business - innovation of contents and teaching.

\section{REFERENCES}

Bačík, R., Fedorko R., Rigelský, M., Sroka, M. \& Turáková, A. (2018). Perceiving the advertising in gender-generational characteristics. In Polish Journal of Management Studies, 1(18), 44-57.

Baumgartner, H. (2002). Toward a Personology of the Consumer: Figure 1. In Journal of Consumer Research, 29(2), 286-292. doi:10.1086/341578

Benko, C. \& Pelster, B. (2013). How Women Decide. Harvard business review. [online]. [201915-09]. Available at: $<$ https://hbr.org/2013/09/how-women-decide $>$.

Birknerová, Z., Frankovský, M., Zbihlejová, L. \& Parová, V. (2017). Gender differences in perception of advertising in the context of expectations of advertising. In Journal of applied economic sciences, 12(6), 1751-1758.

Broadbridge, M. A., Maxwell, G. A. \& Ogden, S. M. (2007). Students' views of retail employment - key findings from Generation Ys. In International Journal of Retail \& Distribution Management, 35(12), 1-19.

Ercis, A. \& Unalan, M. (2017). Relationship among big five personality traits, compulsive buying and variety seeking. In Journal of Management, Marketing and Logistics, 4(3), 217-223.

Giovannini, S., Xu, Y., \& Thomas, J. (2015). Luxury fashion consumption and Generation Y consumers. In Journal of Fashion Marketing and Management: An International Journal, 19(1), 22-40.

Gosling, S. D., Rentfrow, P. J. \& Swann, W. B. (2003). A very brief measure of the Big-Five personality domains. In Journal of Research in Personality.37(6), 504-528.

Hansen, J-I. C. \& Leuty, M. E. (2012). Work Values Across Generations. In Journal of Career Assessment, 20(1), 34-52.

Hershatter, A. \& Eprstein, M. (2010). Millennials and the World of Work: An Organization and Management Perspective. In Journal of Business \& Psychology, 25(2), 211-223.

Homburg, Ch. \& Stock, R.M. (2005). Exploring the conditions under which salesperson work satisfaction can lead to customer satisfaction. Psychology \& Marketing, 22(5), 393-420.

IBM, 2017. Despite Living a Digital Life, 98 Percent of Generation Z Still Shop In-Store. [online]. [2019-22-09]. Available at: https://www03.ibm.com/press/us/en/pressrelease/51397. wss

Janovská, A. (2011). Subjektívna pohoda učitel'ov a jej vzt’ah k osobnostným a interpersonálnym činitel'om. Disertation. Pavol Jozef Šafárik University in Košice.

Jones, E., Moore, J.N., Stanaland, A. \& Rosalind, A.J. (1998). Salesperson Race and Gender and the Access and Legitimacy Paradigm: Does Difference Make a Difference? In Journal of Personal Selling \& Sales Management, 18(4), 71-88.

Kane, S. (2019). Traditionalists (aka The Silent Generation). [online]. [2019-15-09]. Available at: $<\mathrm{http}$ ://legalcareers.about.com/od/practicetips/a/Traditionalists.htm>. 
Kumar, P. (2014). Managing Career Aspiration of Generation Y - A Key to Business Excellence. In Global Journal of Multidisciplinary Studies, 3(5), 114-118.

Lin, C. H. (2011). Personality, value, life style and postmodernism consumer behavior: a comparison among three generations. In International Journal of Organizational Innovation, $3(3), 203-230$.

Littrell, M. A., Jin Ma, Y. \& Halepete, J. (2005). Generation X, Baby Boomers, and Swing: marketing fair trade apparel. In Journal of Fashion Marketing and Management: An International Journal, 9(4), 407-419. doi:10.1108/13612020510620786

Mainland, B. (2012). Why you should segment your target market by generation. [online]. [201922-09]. Available at: $<$ https://www.dynamicbusiness.com.au/small-businessresources/ starting/segmenting-your-target-market-via generations-20102012.html>.

Mitchell, V.W. \& Walsh, G. (2006). Gender differences in German consumer decision making styles. In Journal of Consumer Behaviour. 3(4), 331-346.

Robinson, M. T. (2018). The Generations. Which Generation are You? [online]. [2019-09-09]. Available at: $<$ https://www. career planner. com/Career-Articles/Generations.cfm $>$.

McCrae, R. R., \& John, O. P. (1992). An Introduction to the Five-Factor Model and Its Applications. In Journal of Personality, 60(2), 175-215. doi:10.1111/j.1467-6494.1992.tb00970.x

McAdams, D. P. (2001). The person: An integrated introduction to personality psychology (3rd ed.). Fort Worth, TX, US: Harcourt College Publishers.

McCrae, R. R. \& Costa, P. T. (1990). Personality in Adulthood, Guildford Press, New York.

Nga, J. K. H., \& Ken Yien, L. (2013). The influence of personality trait and demographics on financial decision making among Generation Y. Young Consumers, 14(3), 230-243.

Rahim, F. F. M., \& Rahim, H. A. (2018). The Effect of Personality Traits (Big-Five), Materialism and Stress on Malaysian Generation Y Compulsive Buying Behaviour. In International Journal of Academic Research in Business and Social Sciences, 8(7), 349-362.

Ray, R. H. (1997). “The emerging culture”, American Demographics.19(2), 9-34.

Ratnawat R.G. \& Borgave S. A. (2019). Impact of Big-Five Personality on Impulsive Buying Behaviour. In International Journal of Multidisciplinary, 4(6), 500-505.

Williams, K. C., \& Page, R. A. (2011). Marketing to the generations. In Journal of Behavioral Studies in Business, 3(1), 37-53. 